\author{
AnNa GrabowieC \\ Uniwersytet Marii Curie-Skłodowskiej w Lublinie \\ https://orcid.org/0000-0002-2096-649X
}

\title{
NAUCZYCIEL W OBLICZU KRZYWDY DZIECKA
}

\begin{abstract}
Streszczenie: Spośród różnych dysfunkcji i patologii dotykających współczesne rodziny szczególnie częste i niszczące są przemoc i alkoholizm. W artykule autorka krótko przedstawia konsekwencje wychowywania się w rodzinie z problemem alkoholowym oraz doświadczania przez dziecko przemocy ze strony najbliższych. Następnie podejmuje refleksję na temat miejsca oraz roli szkoły i nauczyciela w systemie pomocy dzieciom z rodzin alkoholowych i dzieciom-ofiarom przemocy domowej.
\end{abstract}

Słowa kluczowe: dziecko, przemoc w rodzinie, rodzina z problemem alkoholowym, nauczyciel, szkoła

[...] nie da się przygotować nauczyciela na wszelka okoliczność zawodowego działania. Te niedoświadczone sytuacje, z którymi nauczyciel spotyka się coraz częściej, muszą być podjęte, mimo nieznajomości ich rozwiązywaniania. Za wypracowanie tych sposobów działania nauczyciel odpowiada sam. (Kwiatkowska 2012, s. 179)

\section{WPROWADZENIE}

Nie ulega wątpliwości, że rodzina jest pierwszym i najważniejszym środowiskiem wychowawczym. Jeśli funkcjonuje prawidłowo, zaspokaja podstawowe potrzeby dziecka, stwarza niezbędne warunki do prawidłowego rozwoju psychofizycznego, wprowadza w świat wartości i norm społecznych, przygotowuje do właściwego pełnienia ról społecznych oraz uczy zaradności życiowej. Na podstawie relacji z najbliższymi u dziecka kształtuje się obraz samego siebie i obraz drugiego człowieka. Interakcje, w których uczestniczy w rodzinie, stanowią dla niego pro- 
totyp wzorów interakcji przenoszonych do innych środowisk. Rodzice, troszcząc się o prawidłowy rozwój swojego potomstwa, przygotowują je tym samym do samodzielnego i sensownego kierowania własnym życiem (Rostowska 2005, s. 33-35; Porąbaniec 2011, s. 85).

Jak podkreśla Stanisław Kawula (2014, s. 129-130), w rodzinie funkcjonalnej „dziecko jest cenne przez sam fakt, że się urodziło”. Bezwarunkowa miłość i szacunek ze strony rodziców stają się dla niego podstawą wysokiego poczucia własnej wartości. Rodzice rozpoznają, uznają i szanują prawa dziecka do myśli, uczuć i zachowań. Nigdy nie atakują swojego dziecka fizycznie czy emocjonalnie a w przypadku poniżających zachowań wobec dziecka ze strony innych ludzi wkraczają i otaczają je ochroną.

Nie wszystkie rodziny potrafią organizować życie rodzinne tak, by w sposób racjonalny podejmować działania opiekuńcze i wychowawcze, pełnić swoje funkcje, pomyślnie rozwiązywać problemy i radzić sobie w sytuacjach kryzysowych. Rodzina, która tego nie potrafi, staje się rodziną dysfunkcyjną (Kawula 2014, s. 129). Panuje w niej atmosfera emocjonalnego dystansu i chłodu uczuciowego. Rodzice zaniedbują potrzeby dziecka, w niewystarczający sposób chronią je przed codziennymi zagrożeniami, co w konsekwencji prowadzi do braku poczucia bezpieczeństwa i stabilności. Sposób traktowania dziecka przez rodziców jest dla niego źródłem przykrości i cierpienia, często doznaje ono poczucia niesprawiedliwości i bezsilności wobec swojej sytuacji (Ryś 2007, s. 79-81). Józefa Brągiel (1996, s. 41-42) mówi nawet o krzywdzie dziecka żyjącego w rodzinie dysfunkcyjnej.

Rodziny dysfunkcyjne zazwyczaj negują istnienie problemów wewnątrz rodziny lub pomijają je milczeniem. Pojawianie się wielu kłamstw i manipulacji prowadzi do zubożenia kontaktów i braku wzajemnego zrozumienia. Dzieci boją się komukolwiek zwierzyć ze swoich problemów, gdyż rodzice utrzymują je w przeświadczeniu, że nie rozmawia się z innymi o tym, co się dzieje w domu (Ryś 2007, s. 79-81).

Dzieci, które wzrastają w rodzinie dysfunkcyjnej, zmuszone są do zaadaptowania się do trudnej dla nich sytuacji. Taką formę adaptacji stanowi przyjmowanie przez nie określonych ról związanych z postawą obronną wobec zagrożeń, z którymi stykają się na co dzień. W literaturze przedmiotu najczęściej wymieniane są role Bohatera Rodzinnego, Kozła Ofiarnego, Zagubionego Dziecka i Maskotki. Ich podejmowanie odbywa się w sposób nieświadomy, a typ wybranej roli zależy m.in. od kolejności narodzin, płci, temperamentu, zdolności i możliwości dziecka oraz zmian wynikających z cyklu życia rodziny. Role, które pozwalają dziecku przetrwać $\mathrm{w}$ rodzinie, często utrwalają się $\mathrm{w}$ formie określonego widzenia świata i konkretnych zachowań jednostki w sytuacjach, w których nie ma żadnej potrzeby kierowania się wyuczonymi reakcjami obronnymi (Cierpiałkowska 2010, s. 263; Ryś 2011, s. 97-101). 
Spośród różnych dysfunkcji i patologii dotykających polskie rodziny szczególnie częste są przemoc i alkoholizm.

\section{DZIECI W RODZINACH Z PROBLEMEM ALKOHOLOWYM}

Rodzina z problemem alkoholowym (alkoholowa) to rodzina, w której jedno z rodziców (czasami oboje) pije w sposób nadmierny, destrukcyjny lub niekontrolowany (Sztander 1993, s. 29). Według danych Państwowej Agencji Rozwiązywania Problemów Alkoholowych w Polsce żyje ponad 850 tysięcy osób uzależnionych od alkoholu, a ponad 2 miliony pije w sposób szkodliwy. Większość z nich pozostaje w związkach małżeńskich lub partnerskich i ma potomstwo. Liczbę niepełnoletnich dzieci wychowujących się w rodzinach z problemem alkoholowym szacuje się na 2 miliony (za: Cierpiałkowska, Grzegorzewska 2016, s. 7).

Uzależnienie od alkoholu u któregoś z rodziców w sposób istotny zakłóca podstawowe funkcje rodziny, zwłaszcza opiekuńczo-wychowawczą. Wyniki badań pokazują, że dzieci alkoholików są trzykrotnie bardziej narażone na przemoc i czterokrotnie bardziej na zaniedbywanie w porównaniu do dzieci, których rodzice nie są uzależnieni (Jaudes i in. 1995, za: Izdebska, Lewandowska 2012, s. 126).

Życie w rodzinie, w której rodzic pije patologicznie, jest związane ze stanem chronicznego napięcia i dostarcza wielu bolesnych przeżyć, z jakimi dziecku trudno sobie w samotności poradzić. Odczuwa lęk o siebie, o rodzinę i pijącego rodzica, a także złość $\mathrm{z}$ nie zawsze łatwych do zrozumienia powodów. Ma również poczucie krzywdy spowodowane wielokrotnym doświadczaniem niezaspokojenia potrzeb, pociągające za sobą cierpienie i rozczarowania (Pacewicz, Strzemieczny 1994, s. 129-130).

Jak wynika z badań dotyczących konsekwencji wychowywania się w rodzinach z problemem alkoholowym, dzieci alkoholików mają bardziej nasilone problemy z zachowaniem niż ich rówieśnicy z rodzin bez problemu alkoholowego. W wieku 6-17 lat wykazują liczniejsze objawy nadpobudliwości psychoruchowej z deficytem uwagi i kontroli zachowania oraz zaburzeń opozycyjno-buntowniczych. Dzieci pijących rodziców mają również więcej kłopotów szkolnych: częściej wagarują, powtarzają klasę bądź nie kończą szkoły (Park, Schepp 2015; Sher 1997, za: Cierpiałkowska, Grzegorzewska 2016, s. 172-176).

Dzieci uzależnionych rodziców znajdują się w grupie podwyższonego ryzyka występowania różnych zaburzeń psychicznych i przystosowawczych. Badania porównawcze najczęściej wskazują na zwiększone ryzyko pojawienia się u nich takich problemów psychicznych jak uogólnione zaburzenia lękowe, zaburzenia depresyjne i uzależnienia. Podatność na uzależnienia wśród dzieci alkoholików 
jest czterokrotnie większa niż u dzieci rodziców nieuzależnionych od alkoholu. Najczęściej występujące problemy przystosowawcze dotyczą zaburzeń związanych z kontaktami społecznymi i bliskimi relacjami, samooceną oraz podejmowaniem ról życiowych. Wykazano również, że dzieci alkoholików w porównaniu do rówieśników z rodzin funkcjonalnych charakteryzują się wyższym poziomem negatywnej emocjonalności, są bardziej samotne i wyobcowane oraz częściej cierpią na zaburzenia związane ze stresem (Anda i in. 2002; Bijttebier, Goethals, Ansoms 2006; Harter 2000; Schuckit i in. 2009; Hall, Webster 2007, za: Gąsior, Chodkiewicz 2015, s. 182; Goodwin 1985; Elkins i in. 2004, za: Cierpiałkowska, Grzegorzewska 2016, s. 173-175).

\section{DZIECI-OFIARY PRZEMOCY W RODZINIE}

Przemoc wobec dziecka to

wszelkie formy fizycznego i emocjonalnego złego traktowania, wykorzystania seksualnego, zaniedbywania lub niedbałego traktowania, komercyjnej bądź innej eksploatacji dziecka, które powodują rzeczywiste lub potencjalne zagrożenie dla jego zdrowia, przetrwania, rozwoju i godności, które mają miejsce w relacji odpowiedzialności za dziecko, zaufania lub przewagi (Jarosz 2015, s. 16).

W literaturze przedmiotu najczęściej przedstawia się cztery formy przemocy wobec dziecka w rodzinie: fizyczną, psychiczną, seksualną i zaniedbywanie. Przemoc fizyczna obejmuje wszelkie nieprzypadkowe zachowania z użyciem siły fizycznej, w wyniku których dziecko doznaje bólu oraz cierpienia i których rezultatem mogą być jakiekolwiek urazy. Ta forma przemocy występuje również w sytuacji świadomego niezapobiegania urazom lub cierpieniu fizycznemu dziecka (Jarosz, Nowak 2012, s. 21). Przemoc psychiczna (emocjonalna) oznacza wszystkie nacechowane wrogością lub obojętnością zachowania rodziców, które niszczą w dziecku poczucie własnej wartości, obniżają zdolność uczenia się, wywołują poczucie bycia niekochanym i uniemożliwiają mu prawidłowy rozwój (Iwaniec 2003, s. 26). Działaniami uznawanymi za krzywdzenie psychiczne są m.in.: upokarzanie, oczernianie, straszenie, dyskryminowanie, wzbudzanie poczucia winy, nieliczenie się z możliwościami rozwojowymi dziecka, nadmierne ograniczanie swobody, wyśmiewanie oraz inne niefizyczne formy wrogiego lub odrzucającego traktowania (Włodarczyk 2017, s. 194). Przemoc seksualna (wykorzystywanie seksualne) z kolei ma miejsce wtedy, kiedy osoba dojrzała seksualnie przez świadome działanie, jak też przez zaniedbanie swoich społecznych obowiązków, dopuszcza 
się zaangażowania dziecka w jakąkolwiek aktywność natury seksualnej mającą na celu uzyskanie satysfakcji erotycznej przez osobę dorosłą (Jarosz, Nowak 2012, s. 22). Specyficzną formą przemocy jest natomiast zaniedbywanie dziecka, bowiem $\mathrm{w}$ przeciwieństwie do pozostałych form nie musi mieć charakteru aktywnego działania. Oznacza chroniczne lub incydentalne niezaspokajanie przez rodziców podstawowych potrzeb egzystencjalnych dziecka, nierespektowanie jego fundamentalnych praw, warunkujących prawidłowy rozwój fizyczny i psychiczny oraz dobry stan zdrowia, jak również narażanie dziecka na jakiekolwiek niebezpieczeństwo. Może dotyczyć różnych potrzeb rozwojowych dziecka, dlatego mówimy o zaniedbywaniu fizycznym, medycznym, emocjonalnym, edukacyjnym. Skrajną formą zaniedbania dziecka jest porzucenie go (Kolankiewicz 2012, s. 81-87).

Stosowanie przemocy w wychowaniu i opiece nad dziećmi, mimo obowiązującego w Polsce zakazu, praktykuje się nadal w wielu domach. Z policyjnych statystyk wynika, że w 2017 roku liczba małoletnich ofiar przemocy w rodzinie wynosiła ponad 13,5 tysiąca przypadków (Przemoc w rodzinie 2017).

Doświadczanie przemocy ze strony najbliższych osób jest jednym z największych zagrożeń dla rozwoju dziecka. Czyni ogromne spustoszenie w jego więzi z rodzicami, co bezpośrednio wpływa na poczucie bezpieczeństwa oraz umiejętność nawiązywania dobrych relacji z innymi ludźmi.

Skutki doznawania przemocy mają charakter zarówno bezpośredni, jak i długotrwały, co oznacza, że powodują wiele problemów i dysfunkcji w dorosłym życiu jednostki. Bezpośrednimi reakcjami dzieci na krzywdę mogą być: agresja i zachowania destrukcyjne, emocjonalna labilność, poczucie winy, zaburzenia $\mathrm{w}$ relacjach z rówieśnikami, wrogość do otoczenia przy jednoczesnym silnym przywiązaniu do opiekunów, niska samoocena, nadpobudliwość psychoruchowa, zachowania opozycyjno-buntownicze, zaburzenia koncentracji, pogorszenie wyników w nauce (Pospiszyl 1994, s. 156-161).

\section{NAUCZYCIEL W SYSTEMIE POMOCY I WSPARCIA DLA DZIECKA DOŚWIADCZAJĄCEGO KRZYWDY W RODZINIE}

Jednym z ważniejszych czynników, które mogą wpływać na to, jaki ślad pozostawi w psychice doświadczanie krzywdy, jest szybka i adekwatna pomoc. Sytuacja w każdej rodzinie dysfunkcyjnej - czy to z problemem przemocy domowej, czy z problemem alkoholowym - wygląda inaczej, ale zawsze nieodzowne jest udzielenie pomocy. Jedno z podstawowych miejsc, w którym dziecko krzywdzone powinno uzyskać wsparcie to szkoła, bowiem - jak wskazują dotychczasowe badania negatywne skutki stresu przeżywanego przez dziecko w rodzinie mogą zostać 
pomniejszone przez pozytywne doświadczenia z życia szkolnego. Wspierająca postawa osoby dorosłej spoza rodziny potrafi w sposób istotny redukować siłę działania niekorzystnych okoliczności życiowych, w których znalazło się dziecko. W literaturze podkreśla się istotną rolę pozytywnych doświadczeń edukacyjnych młodych osób w kształtowaniu odporności psychicznej, zwłaszcza jeśli istnieje zagrożenie psychopatologią. Więzi łączące uczniów ze szkołą mają silne działanie chroniące przed zachowaniami ryzykownymi, np. nadmiernym spożywaniem alkoholu i innych substancji psychoaktywnych (Resnick i in. 1997, za: Cierpiałkowska, Grzegorzewska 2016, s. 156). Badania longitudinalne prowadzone przez Emmy Werner i Ruth Smith (1982, za: Grzegorzewska 2011, s. 230-231) wykazały, że prawie $1 / 3$ badanych dzieci $z$ rodzin alkoholowych wyrosła na dobrze przystosowanych dorosłych, a jednym z najsilniejszych predyktorów ich odporności psychicznej było wsparcie społeczne otrzymywane w środowisku szkolnym ze strony dorosłych. Nie do przecenienia wydają się zatem profesjonalna pomoc i wspierająca postawa nauczyciela, który dzięki codziennym kontaktom z uczniami ma wyjątkową możliwość zwrócenia uwagi na ich problemy i zmiany w zachowaniu oraz zauważenia fizycznych symptomów przemocy.

Dzieci krzywdzone „nie mają zwyczaju” ujawniać, że potrzebują pomocy. Zwykle wstydzą się opowiadać o swoich trudnych przeżyciach w rodzinie, często nie darzą zaufaniem dorosłych bądź obawiają się, że nikt im nie uwierzy. Dlatego bardzo ważna jest umiejętność rozpoznawania takich dzieci. W sytuacji podejrzenia, że uczeń może być ofiarą przemocy domowej, nauczycielowi niezbędna jest wiedza o mechanizmach i symptomach przemocy oraz znajomość procedury Niebieskiej Karty. Tymczasem, jak wynika z badań CBOS (za: Jarosz, Nowak 2012, s. 193-198), jedynie nieco ponad $1 / 3$ nauczycieli zapytanych o kompetencje w identyfikowaniu dzieci-ofiar przemocy w rodzinie ocenia swoją wiedzę jako wystarczającą i sprawdzającą się w praktyce. Poza tym wielu z nich obawia się odpowiedzialności za ingerencje w sprawy rodzin i podejmowanie decyzji o zgłoszeniu przemocy domowej.

Spojrzenie na sytuację dziecka $\mathrm{z}$ różnych perspektyw (np. dotychczasowego rozwoju i urazów, jakich doznało) oraz dobra znajomość zachowań charakterystycznych dla przyjmowanych przez nie ról w rodzinie pozwalają nauczycielowi postawić trafną diagnozę źródeł problemów wychowawczych i edukacyjnych ucznia oraz zaplanować kierunki działań. Właściwe postępowanie wychowawcze lub dydaktyczne wymaga dostosowania sposobu pracy do rozpoznanej roli. Inaczej należy pracować z Bohaterem Rodzinnym, inaczej z Zagubionym Dzieckiem. Dla każdej z ról skuteczne są inne korekcyjne strategie oddziaływania (Seweryńska 2015, s. 44).

Pomoc dzieciom $\mathrm{z}$ rodzin dysfunkcyjnych polega nie tylko na ustalaniu problemów czy na identyfikowaniu zaburzeń i deficytów, ale również, a może przede 
wszystkim na rozpoznawaniu możliwości, zdolności i zasobów dzieci oraz wzmacnianiu czynników ochronnych związanych z indywidualną charakterystyką młodych ludzi. Niezwykle ważne jest uczenie dzieci krytycznego myślenia, podejmowania refleksji nad konsekwencjami własnych działań i rozwiązywania problemów. Nauczyciele powinni zwracać szczególną uwagę na kształtowanie u uczniów wiary w siebie i w możliwość wpływania na swoją przyszłość, poczucia własnej skuteczności oraz umiejętności radzenia sobie z trudnościami i zmianami. Niezwykle ważne wydaje się budowanie u osób doświadczających krzywdy w rodzinie przekonania, że niesprzyjające okoliczności życiowe są czymś, co można zmieniać, a porażki występują naprzemiennie z sukcesami (Grzegorzewska 2011, s. 46-47). Efektem takiej pomocy powinno być wzmocnienie konstruktywnych strategii radzenia sobie ze stresem, pozbycie się przez dziecko poczucia winy, lęku i osamotnienia, podniesienie samooceny oraz stworzenie spójnej, pozytywnej wizji świata i siebie.

Zdaniem Iwony Grzegorzewskiej (2011, s. 47-48) efektywnym narzędziem ochrony dzieci i młodzieży przed negatywnymi skutkami doświadczania przewlekłego stresu w środowisku rodzinnym mogą okazać się skierowane do wszystkich uczniów programy edukacyjne i wychowawcze promujące kształtowanie odporności psychicznej. Programy te mają na celu przede wszystkim odreagowanie napięcia, poprawę umiejętności komunikowania się z innymi, znalezienie sposobu na wyrażanie swoich emocji i potrzeb, a także nabycie umiejętności radzenia sobie z problemami oraz szukania wsparcia i pomocy w sytuacji zderzenia z problemami.

Należy zaznaczyć, że najważniejszym warunkiem skutecznej pomocy ze strony nauczyciela jest autentyczny kontakt $\mathrm{z}$ dzieckiem. Nauczyciel musi zdawać sobie sprawę z tego, że budowanie więzi i zaufania to proces. Musi być cierpliwym i uważnym słuchaczem i rozmówcą, okazującym dziecku życzliwość i szacunek oraz akceptującym jego uczucia. Powinien również zdawać sobie sprawę z trudności, na jakie może napotkać w pracy z uczniem krzywdzonym, które wynikają z braku zaufania czy poczucia zagrożenia.

\section{PODSUMOWANIE}

Jednym z podstawowych miejsc, w których dzieci wzrastające w rodzinach przemocowych bądź alkoholowych powinny uzyskać pomoc, jest szkoła. Szkoła ze względu na swoje ustawowe zadania zobowiązana jest do zapobiegania krzywdzeniu dzieci oraz do podejmowania działań, gdy są zagrożone, a w szczególności kiedy zagrożenie to pochodzi od samych rodziców. W związku z tym na nauczycielach ciąży obowiązek rozpoznawania, czy prawidłowy rozwój, zdrowie bądź życie dzieci nie są zagrożone. Każdy z nich musi mieć odpowiednią wiedzę i umiejętności, 
które pomogą w sprawnym i efektywnym identyfikowaniu objawów występowania przemocy oraz podejmowaniu pierwszych interwencji (Kita 2011, s. 69).

W szkole dzieci i młodzież spędzają kilka godzin dziennie, dlatego tak ważna wydaje się jej rola w podejmowaniu działań chroniących uczniów z rodzin dysfunkcyjnych przed pogłębianiem się u nich problemów emocjonalnych oraz zapobiegających niedostosowaniu społecznemu. Nauczyciel, mimo iż nie jest terapeutą, to - posiadając odpowiednie umiejętności - może wspierać rozwój młodych ludzi wychowujących się w niesprzyjających warunkach życiowych. Właściwe okazana pomoc uświadamia dzieciom, że nie są same ze swoim problemem, pozwala odreagować emocje odczuwane w domu oraz stwarza możliwość nabycia umiejętności psychospołecznych, które pomagają lepiej radzić sobie z pojawiającymi się trudnościami.

\section{LITERATURA}

Brągiel J., 1996, Zrozumieć dziecko skrzywdzone. Opole, Wydawnictwo UO.

Cierpiałkowska L., 2010, Funkcjonowanie dzieci alkoholików - psychospołeczne źródła deficytów i zasobów. W: L. Cierpiałkowska, M. Ziarko, Psychologia uzależnień alkoholizm. Warszawa, Wydawnictwa Akademickie i Profesjonalne, 253-288.

Gąsior K., Chodkiewicz J., 2015, Doświadczenia z dziecinstwa i aktywność neotyczna a nasilenie problemów psychicznych $u$ dorostych $z$ rodzin z problemem alkoholowym. „Czasopismo Psychologiczne”, nr 2, 181-193.

Grzegorzewska I., 2011, Odporność psychiczna dzieci i młodzieży - wyzwanie dla współczesnej edukacji. „Teraźniejszość - Człowiek - Edukacja”, nr 1, 37-51.

Iwaniec D., 2003, Krzywdzenie emocjonalne a zespół nieorganicznego zaburzenia rozwoju. „Dziecko Krzywdzone. Teoria, Badania, Praktyka”, nr 4, 24-39.

Izdebska A., Lewandowska K., 2012, Czynniki ryzyka krzywdzenia dzieci. „Dziecko Krzywdzone. Teoria, Badania, Praktyka”, nr 2, 116-132.

Jarosz E., 2015, Przemoc w wychowaniu. Między prawnym zakazem a społeczna akceptacją. Warszawa, Biuro Rzecznika Praw Dziecka.

Jarosz E., Nowak A., 2012, Dzieci ofiary przemocy w rodzinie. Warszawa, Biuro Rzecznika Praw Dziecka.

Kawula S., 2014, Rodzina o skumulowanych czynnikach patogennych. W: S. Kawula, J. Brągiel, A. Janke (red.), Pedagogika rodziny. Obszary i panorama problematyki. Toruń, Wydawnictwo Adam Marszałek, 115-152.

Kita B., 2011, Zadania pracowników szkoły w sytuacji rozpoznania lub podejrzenia krzywdzenia dziecka $w$ rodzinie. W: J. Zmarzlik (red.), Przemoc w rodzicie wobec dziecka. Procedury interwencyjne w szkole. Warszawa, Ośrodek Rozwoju Edukacji, 69-81. 
Kolankiewicz M., 2012, Zaniedbywanie dzieci. „Dziecko Krzywdzone. Teoria, Badania, Praktyka”, nr 2, 81-94.

Kwiatkowska H., 2012, Teoriopoznawcze implikacje związku teorii z praktyka $w$ kształceniu akademickim nauczycieli. W: M. Urlińska, A. Uniewska, J. Horowski (red.), „Po życie sięgać nowe ...”. Teoria a praktyka edukacyjna. Toruń, Wydawnictwo Adam Marszałek, 474-489.

Pacewicz A., Strzemieczny J., 1994, Pomoc psychologiczna dla dzieci alkoholików. W: A. Pacewicz (red.), Dzieci alkoholików. Jak je rozumieć, jak im pomagać. Warszawa, Agencja Informacji Użytkowej „Bivar”, 117-144.

Porąbaniec M., 2011, Działania pracowników socjalnych podejmowane na rzecz zapobiegania zjawisku wykluczenia społecznego dzieci i młodzieży z rodzin dysfunkcyjnych. „Pedagogika Rodziny”, nr 1, 83-95.

Pospiszyl I., 1994, Przemoc w rodzinie. Warszawa, Wydawnictwa Szkolne i Pedagogiczne.

Rostowska T., 2005, Transmisja międzypokoleniowa $w$ rodzinie $w$ zakresie wybranych wymiarów osobowości. Łódź, Wydawnictwo UŁ.

Przemoc $w$ rodzinie, 2017, opublikowano: http://statystyka.policja.pl/st/wybrane-statystyki/przemoc-w-rodzinie/50863,Przemoc-w-rodzinie.html [dostęp: 19.07.2018].

Ryś M., 2007, Rodzinne uwarunkowania psychospołeczne funkcjonowania Dorosłych Dzieci Alkoholików. Warszawa, Wydawnictwo Naukowe PWN.

Ryś M., 2011, Role pełnione w rodzinie z problemem alkoholowym a poczucie własnej wartości i relacje interpersonalne z najbliższymi u Dorosłych Dzieci Alkoholików. „Kwartalnik Naukowy Fides et Ratio”, nr 4, 93-130.

Seweryńska A.M., 2015, Uczeń z rodziny dysfunkcyjnej. Ostrów Wielkopolski, Wydawnictwo Perspektywa.

Sztander W., 1993, Dzieci w rodzinie z problemem alkoholowym. Warszawa, Instytut Psychologii Zdrowia i Trzeźwości.

Włodarczyk J., 2017, Przemoc wobec dzieci. „Dziecko Krzywdzone. Teoria, Badania, Praktyka”, nr 1, 192-213.

\title{
A TEACHER FACING A CHILD'S HARM
}

\begin{abstract}
Among the various dysfunctions and pathologies affecting modern families, violence and alcoholism are particularly frequent and destructive. In the article, the author briefly presents the consequences of raising a family with an alcohol-related problem and experiencing violence from close relatives. Then she takes a reflection on the position and role of the school and teacher in the system of helping children from alcoholic families and child-victims of domestic violence.
\end{abstract}

Keywords: children, domestic violence, family with alcohol-related problem, teacher, school 